\title{
Can Non-Muslim Courts bring Legal Change in Sharia Laws?
}

\author{
Hajed A. Alotaibi ${ }^{1}$ \\ ${ }^{1}$ Department of Islamic Contemporary Studies, College of Science and Humanities at Hotat Sudair, Majmaah \\ University, Riyadh, Saudi Arabia \\ Correspondence: Hajed A. Alotaibi, Department of Islamic Contemporary Studies, Faculty of Science and \\ Humanities at Hotat Sudair, Majmaah University, 11952, Riyadh, Saudi Arabia. Tel: 966-5-8002-8990. E-mail: \\ h.alotaibi@mu.edu.sa
}

Received: September 5, 2019

Accepted: October 9, 2019

Online Published: October 30, 2019

doi:10.5539/jpl.v12n4p1

URL: https://doi.org/10.5539/jpl.v12n4p1

\begin{abstract}
The transformative and regulatory accommodation model addresses practical challenges to accommodate religious laws and courts in the secular and democratic regimes. There is strong evidence against the jurisdictional competition between secular and religious courts under defined conditions. There is no concern regarding the Shariah courts in the non-Muslim democracies, a majority of the country's ethno-religious groups control the civil and rabbinical courts. In this regard, there is a need to mitigate the negative impact of Muslim Family Laws (MFLs) by the civil courts in non-Muslim majority countries because MFLs imply certain disabilities and limitations upon the displayed rights of women and children. To address these issues, the present study aims to discuss the possibilities and challenges faced by the multicultural and pluri-legal accommodations by focusing on Islamic law and institutions within the non-Muslim democracies. The results have shown that the reformation of rules and procedures internalize certain principles and discourses due to increased compliance of religious courts with the high court rulings. An increase in the number of Muslim judges on civil courts would help to overcome the lack of legitimacy in the perspectives of the Muslim minority that is the main reason for shortcomings of both ex-post and ex-ante oversight mechanisms.
\end{abstract}

Keywords: family courts, family law, Islam, legal courts, Shariah law

\section{Background}

Multicultural accommodations confer upon positive rights of minimal groups for protecting their different religion-legal traditions specifically when the rights of individuals are associated with the well-intended group throughout the communities. The significance of the right to exit and the role of the state to confirm fundamental rights to group members varies for the content and the degree. For instance, a hands-off policy should be adopted by a liberal state toward illiberal minority cultures to retain a right for group members (Sezgin, 2017). The significance of the internal autonomy of non-ruling minority groups is emphasized for making recommendations for justifying severe physical violence through state intervention communal affairs. These contributions are removed or are largely abstract from the challenges of accommodating religious laws and practices throughout a democratic framework. These contributions understand the multiculturalism to identify and formally conceptualize religious courts or laws throughout their legal systems, precisely (Sezgin, 2018).

Custom or religion-based legal orders are acceptable when the individuals are given the right of choosing between secular and religious laws to get free from their cultural communities. It was not accepted by the scholars, who rejected the pluri-legal accommodations in the family law, categorically. There is a significant difference in the approaches adopted by different scholars based on the extent and content of the right to either exit or explain the role of state to guarantee the basic rights to group members. In a similar context, a study conducted by Kitromilides (2012) argued that hands-off policy towards illiberal minority cultures should be adopted by a liberal state so that the right of group members to exit is retained. Similarly, the significance of the internal autonomy of non-ruling minority groups was emphasized by Barzilai (2010), who suggested that there are only rare instances of severe physical violence justifying the state intervention in communal affairs.

Four countries have made efforts to bring sharia law to their system, which includes Ghana, Israel, India, and Greece. In this regard, two important questions have been emphasized completely in the literature. These questions are the central focal point of this study, which shows the role of secular state institutions to ensure 
fundamental rights and liberties are respected by religious courts in their decision-making. In addition, this study assesses whether there exists a relationship between the religious or the secular law and court presentation in a democratic area.

The transformative and regulatory framework is used for addressing the practical challenges in accommodation for the secular and democratic regimes. For instance, Hacker (2012) developed strong evidence against the jurisdictional competition of the religious and secular courts under defined conditions. This competition helps in communication of the religious internal reforms concerning its practices and norms. Majority of the country's ethno-religious groups control the civil and rabbinical courts; however, no concern exists for the Shariah courts in the non-Muslim democracies. Therefore, certain limitations are present concerning the women and children by State-enforced Muslim Family Laws (MFLs). This requires instigation of the changes in the Islamic laws and courts for addressing the adverse MFLs impact on the Non-Muslim population.

The present study significantly contributes to explaining the possibilities and challenges faced by the multicultural and pluri-legal accommodations. This is accomplished by studying the non-Muslim democracies and the present Islamic law and institutions within it. This study is primarily based on secondary data extracted by the researcher through observations and rulings of litigants, experts, lawyers, and judges in three non-Muslim countries including Greece, Israel, and India between 2004 and 2015. The researcher has investigated several published and unpublished court decisions for this study. Electronic subscription-based databases were used to obtain civil court decisions. The rulings of judges and civil courts were extracted by using keyword searches such as Hadith, Nikah, Faraiz, Quran, Sharia, Muslim Family Laws, Civil Courts, and Sharia Courts.

The article is organized as follows. Section 1 presents general insights on the civil-religious court relations, presenting insights of both civil courts and Muslim courts. Section 2 presents information about the civil courts and Muslim family law practiced in non-Muslim countries. In the $3^{\text {rd }}$ section, jurisdictional competition and internal reforms are explained for both Greece and Israel civil courts. Civil court rulings and decisions of judges are discussed in this section, too. Section 4 presents the regulations of sharia courts from the perspective of Indian Muslims. The rulings and decisions, in this section, are presented in general and practical aspects. In conclusion, the overall experience of non-Muslim countries selected in this study towards civil courts and sharia courts has been summarized. Lessons learned from the cases have been discussed for future implications.

\section{Civil-Religious Court Relations}

Forum-shop and concurrent jurisdictions can be used by the Muslim litigants between the religious and civil laws/courts with less preference to the civil courts. Jurisdictional competition is promoted through forum-shopping. When a rival forum individual fails to systematically resolve a specific individual's class whereas pro-plaintiff measures are increasingly adopted by the other for increasing the competition for textual and clientele authority (Bowen, 2018). The pressure might be felt by religious courts for undertaking self-reform to retain their clientele and authority when competition from the civil courts' increases. Although lower civil courts play a substantial role, they serve as an internal change instrument. The ruling of religious court review is performed by hierarchical superiors of higher civil courts, though limited and equivocal court. The burden concerning the violation of human rights is imposed by the superior courts as well as breaches on at-risk groups and vulnerable groups (Lindsey, 2016). The religious courts share jurisdiction in a majority of the non-Muslim countries that are concurrent with lower civil courts. Muslim litigants can take advantages of the concurrent jurisdictions that are present in the religious and civil courts. Promotion of jurisdictional competition through forum shopping was suggested by Shachar (2001). Rival forms failure for addressing individuals' certain class increases competition for the textual and clientele authority. However, it may adopt the provision of larger maintenance that highlights the increased pro-plaintiff measures (Klerman, 2014). Religious courts experience pressure for undertaking self-reforms to retain their clientele and authority to face competitions from the civil courts. For the religious judiciary, the lower civil courts pressure increases when there is an increase in the jurisdictional competition, which is likely to impose greater chances of adopting market-induced reforms in the MFLs.

The lower civil courts are considered to be a significant but indirect source of bringing about internal change in the religious laws, based on the conceptualization provided by Shachar (2001). In contrast, the higher civil courts including the constitutional courts and supreme courts have the authority to review the ex-post constitution concerning the rulings of the court and they are the hierarchical superiors of religious courts. These courts also have a more equivocal but limited role. The allegation of the human rights breaches and violation burden is placed on the vulnerable individuals, who have been pressurized to accept the jurisdiction of religious courts by the superior courts, which review the ex-post judication. Therefore, it is suggested to rely on the adoption of 
additional ex-ante oversight mechanisms, rather than the ex-post review. Shachar (2001) argued that 'change from within' can be brought through continuous usage of ex-ante oversight techniques. Moreover, religious judges need to exercise self-restraint to avoid a clash with statutory laws and internalize the secular norms, voluntarily.

The Shachars' devised ex-post review reservations and limitations were suitable for the Shariah courts and secular high courts in the non-Muslim countries. The Muslim litigant finds challenging to contrary the religious courts in a setting where the higher civil court was the major regulator of the Muslim minority. Therefore, Muslim-minority setting experiences language and ideological restriction concerning plaintiffs as they challenged the communal courts appealing. Shachar (2001) research stated ex-post judicial review limitation can be overcome through the complementary ex-ante oversight techniques use, which instigate internal change in the religious courts. MFL democracies use various ex-ante oversight mechanisms for controlling the practices of Islamic courts.

\section{Civil Courts and Muslim Family Law}

Infringement towards natural justice principles' and disregard for binding statutory rules are involved in each sharia justices of the higher court of justice, where the disruption is restricted to involved ultra vires cases. For instance, HCJ ruled itself as acting ultra vires, if a sharia court restricts itself to the religious law irrespective of the secular legislation. The court continues to stop the application of secular laws responsible for sharia courts and reminded them that statutory laws will be ignored under their rulings (Mohammad \& Kusrin, 2017). A pragmatic approach toward the HCJ is embraced by the first two generations that usually comply with secular laws for avoiding the civil judiciary relationship with direct conflict.

MFLs have been integrated into the legal systems of around 53 countries in recent times (Sezgin, 2017). However, significant variation prevails concerning the manner and degree to which a country incorporates MFL into its regulatory system. These countries might adopt either conservative interpretations or liberal interpretations. Based on this variation, countries incorporating MFL can be grouped into three scenarios;

- Countries that integrate religious laws in the national system and also applicable at the civil courts with the approval of secularly trained judges.

- Countries that apply the specialized Shariah courts.

- Countries that apply the state-recognized religious authorities without the involvement of any formal court system.

Previously, the application of MFL in the legal system might affect women and children's human rights (Esposito and DeLong-Bas, 2001). For the constitutional and international law, the application of group-based rights was done as per the Muslim communities given their frequently reported crash with liberties and individual rights. Based on the transformative accommodation, the secular, as well as religious courts, are likely to share the jurisdiction through the use of a specific subject-matter rather than a separate complementary sub-matter. Such as family matters that include alimony, custody, and property are categorized under the civil courts' jurisdiction; whereas marriage and divorce-related matters fall under the religious court's purview. Individuals are offered concurrent jurisdictions by the religious and civil courts for transferring their disputes from one system of the court to another. This usually happens, when individuals know that the system of prevailing jurisdiction has failed to address their concerns. The civil courts are responsible for administrating MFLs and interacting with religious courts based on two types;

- Lower courts that are specialized family courts responsible for sharing the concurrent jurisdiction with the religious courts.

- High courts are at a supreme level and are engaged with the supervisory powers.

The model of transformative accommodation helps to analyze the relations that exist between the lower civil and Islamic courts. Concerning the MFLs regulation and administration, the transformative accommodation model helps to identify the direct as well as the indirect role played by the civil courts. The religious courts in the majority of the non-Muslim countries are likely to share jurisdiction that is parallel to the civil courts. This might be advantageous for the Muslim litigants because of synchronization between the jurisdictions of civil and religious courts. Jurisdictional competition is likely to be promoted through forum-shopping as stated by Shachar (2001). The failure of one of the rival forums addressing the concerns of certain individuals results in increased competition for clientele and textual authority. This allows the adoption of pro-plaintiff measures; for instance, the child support awards and granting of large maintenance (Klerman, 2014). The arousal of competition among the civil courts is likely to pressurize the religious courts for undertaking self-reform for retaining their clientele 
and authority. The chances of market-induced reforms in MFLs increased as a result of increased jurisdictional competition. The apostasy outcomes are detrimental to the children's custody as per the sharia. In Haifa, the custody rights were revoked by the regional sharia for the mothers, reportedly converted from Islam to Christianity. The HCJ reversed the decisions of SCA claiming that the welfare officers' reports were disregarded by the religious court regarding children's wellbeing and were solely based on religious aspects, even though the Haifa court ruling was upheld the SCA (Sezgin, 2018).

To be precise, the HCJ has rejected the religion-based interpretation of the court due to lack of subsequent professional justification, though the principles of the sharia court were used for ensuring the child wellbeing (Ramadan, 2015). In contrast, the tolerable quality of the High Court is rare concerning the secular selection interpretation as well as principles for limiting its interrelation for the religious court, which complies with the normative outcomes and procedural requirements sought by the HCJ. For example, the HCJ decision not to intervene was consistent with welfare officer recommendations, although the Taibe court used religious considerations for ensuring its decision alignment (Sandberg \& Sandberg, 2017).

\section{Jurisdictional Competition and Internal Reform}

Sharia courts enjoy several benefits concerning its structure over its competition counterparts. Muslim litigants are concerned by all Arabic-Muslim sharia court judges as well as are well-recognized with their culture. Almost half of this population speaks Hebrew, who are not fundamentally recognized with cultural and religious practices and Muslim customs in family courts. The Arab citizens are not provided with pro bono translation services by the family courts. Shariah courts ease to execute the submission procedure and claim. At religious courts, the proceedings are short and are automatically exempted for application and fees filing in alimony and child maintenance cases is granted to the women. However, this application requires formal approval to be exempted from the family courts (Kayan, 2011). Also, pro bono translation services are not provided by family courts for Arab citizens. Secondly, sharia courts easily claim submission and the proceedings of the court.

The comparative advantage for the pecuniary awards keeps the family courts within the game. As compared to the awards made by the Shariah courts, the civil family courts introduced spousal alimony and child support awards are found to be more effective and efficient. This difference encourages female Muslim litigants for choosing civil family courts rather than Islamic courts; although, they find its accessibility difficult. Islamic and civil compete concerning the client's interpretation of the divine law concerned with the child custody and maintenance cases. Hebrew textbooks, as well as English sources, serves as the primary source of information for Jewish judges. These judges are normally lacking Arabic as well as Islamic training. Muslim law was applied by the civil family court judges in 2001 after the Jewish law application since 1953.

In Muslim marriage, the institution of ihtibas provides foundation of the spousal obligations and duties. Ihtibas is the wife's duty for devoting herself to her husband. According to the judges, the woman is declared to be disobedient if she leaves her husband's home without his permission. A woman loses her right to maintenance if she is determined to be disobedient. The judges mainly focus on the burden on the husband concerning all the decisions dealing with ihtibas. However, the wife is responsible for proving herself, if she had left his home. She needs to clarify that she was not involved in any of the violating act and that her departure was justified. The Shariah laws overlook certain types of violence; for instance, occasional violence by the husband to educate and discipline the wife. A case appearing in the family court declared wife to be disobedient as she had left home because of alleged verbal assault by the husband. The Shariah law declared that duty of confinement violation does not consider verbal abuse for violating the confinement duty because it allows the husband to abuse his wife by light beatings.

The child support cases are represented with a similar conservative and patriarchal tone. Islamic law has made the father responsible for his children and no contribution has to be made by the mother for upbringing her children, even if she is wealthy and capable. The family courts have overlooked the analogous Islamic law inequality and continued consideration that the child needs are provided by the Muslim men; although, they have challenged the inequality among the child support laws. The courts need to uphold the conservative and patriarchal view of Shariah for awarding more support and alimony to the child. Since the last two decades, this dynamic is known to be an important aspect of competition between family courts and Shariah laws (Shahar, 2016). The 2001 amendment of the Working Group for Equality in Personal Status Issues (WGEPSI) encourages that Shariah courts reduced jurisdiction is observed for cases related to the maintenance, custody, as well as child support. A new law lobbying was immediately observed to reduce the religious court jurisdiction after the foundation of the coalition in 1995. According to Shahar (2016), Shariah courts have realized that business would make them lose their jurisdiction. Therefore, a new judicial decree was issued after getting engaged in the 
self-reform, which resulted in increased appeal of courts for the female litigants. This allows for raising the maintenance awards amount via innovation in the procedure. The spousal maintenance awards by the Shariah courts increased by $50 \%$ following the new judicial decree issuance (Shahar, 2016). However, substantive and procedural reforms in other areas were undertaken by the Islamic judiciary for civil courts instigated appeal and competitiveness through civil courts.

From theoretical perspectives, conservative rulings are observed for Greek civil courts concerning muftis and Islamic law. The muftis' legal independence was developed and confirmed by international treaties as an important protection element for the reciprocal minority between Greece and Turkey (Turner \& Arslan, 2015). Questions related to Islamic law was not only based on legality, but also on diplomatic, security, and political concerns. Turkish-Greek relations raised to a new stage of agreement similar to the European Union commencement to accessed negotiations with Turkey, in the late 1990s and 2000s. Concerning the policy protection of the minority, the Greek government, at the same time, took multiple steps for improving the Muslim socio-economic in Thrace (Grigoriadis, 2008; Memisoglu, 2007).

Similarly, the ruling of Appeals Court of Thrace showed that managing mufti jurisdiction does not include parent-child relations though it includes the civil courts' purview (Tsavousoglou, 2015). The property relationship of the spousal is to be excluded from the mufti jurisdiction. Also, the mufti's jurisdictional competence does not hold child custody ruling of the civil court, which forms the decision based on parental authority's concept of narrow interpretation (Sezgin, 2017). Likewise, inheritance from mufti jurisdiction was excluded from regional courts, which lead Greek citizens to civil courts, irrespective of religion.

\section{Sharia Courts and Indian Muslims}

The life of millions of Muslims in India has been regulated by the Muslim Personal Law Shariah Application Act of 1937. It offers Islamic code that applies to the Muslim community. The act encourages nevertheless any usage or customs in all aspects of rights of inheritance, special property of females, legacies of women, and preferences, which include personal property inherited. Moreover, the dissolution of marriage, maintenance, dower, trusts and trust properties, and wakfs are regulated in the act (Rani, 2014). The Shariah Application Act 1937 emerged when the British-Indian Government was making efforts to subverting Islamic law and its application to the Indian Muslims to bring into consideration the social reforms.

The Jamiat al-Ulema Hind spearheaded the movement for expressing their resentment alongside the actions of the government in response to the British-Indian Government's move. The initiatives of government drew the shape of the leading ulemas or religious scholars of the country who assumed it as their religious obligation for creating awareness among the Muslim community of the negative concepts of the government for uprooting Islamic law. Therefore, an extremely important campaign was conducted within the country for persuading Muslims to follow Islamic Sharia. Parallel efforts were made by ulemas to terminate several un-Islamic practices among different sections of the Muslim community in the country along with the campaign alongside the actions of government (Lemons, 2018). Access to justice delivery was improved by the sharia courts through cost-reduction strategies with bureaucratic delay and with the requirement for professional help and lowering the discouragement of possible stakeholders who are challenged in regular courts by lawyers and judges of higher social status as compared to themselves.

Sharia courts using mediation bring into consideration shared societal interests and reassures social connections because litigation is considered a negative social phenomenon, which leads to the disruption of social relationships. Improving community peace and larger social harmony using mediation is the perceptible expression of sharia courts. The institution can be effectively explained as an internal community regulatory mechanism. Today, sharia courts are essential alternative dispute resolution (ADR) mechanisms and; therefore, its role is harmonizing to the formal judiciary. Sharia courts or dar-ul-qaza is an important dispute redressal forum for the Indian Muslims as they can address disputes cordially and expeditiously. The dar-ul-qaza is complementing the formal Indian judiciary by settling private disputes of such a larger community as that of the Muslims. The system is inspired by the ideal service to mankind, apart from its complementary role. The dar-ul-qaza create a more flexible and precise instrument for dispute adjudication using its formal approach, in a developing country like India, and lower the insecurity and uncertainty that appear from the formal legal system rigidity. The sharia courts are comprehensively adapted to the profile and needs of its community members.

\section{Conclusion}

The lack of necessary moral authority results in the failure of the civil courts to bring direct changes in MFLs in non-Muslim countries. Self-reforms are undertaken as a result of influence of the civil courts that pressurize the religious courts and judges indirectly. Even though they opposed the HCJ interventions into Islamic jurisdictions, 
sharia courts will subtly and selectively comply with rulings of the high court, specifically those for which they can reveal an Islamic justification. Sharia courts further based their operation under lateral burden from civil family courts to top-down pressure of HCJ. The religious courts are pressurized to align their practices to the decisions of high courts; whereas, the religious courts' compliance with the higher court decision requires certain changes including substantive rules and procedures. The conflicting relationship between the two court systems does not favor substantive rules and procedural changes. There is increased compliance of religious courts with the high court rulings, which results in the reformation of rules and procedures to internalize certain principles and discourses. The perception of the civil judiciary concerning Muslim minority lack of legitimacy is among the main shortcoming reasons for both ex-post and ex-ante oversight mechanisms. However, an increase in Muslim judges on civil courts would help in overcoming this hurdle.

\section{Acknowledgments}

The author is very thankful to all the associated personnel in any reference that contributed in/for the purpose of this research. The author would also like to thank Deanship of Scientific Research at Majmaah University for supporting this work under Project Number No. R-1441-6 I would additionally like to thank the editing board and reviewers for their valuable responses and fast reply.

\section{References}

Barzilai, G. (2010). Communities and law: Politics and cultures of legal identities. University of Michigan Press. https://doi.org/10.3998/mpub.17817

Bowen, J. R. (2018). Gender, Islam, and law. Towards Gender Equity in Development, 277. https://doi.org/10.1093/oso/9780198829591.003.0013

Esposito, J. L., \& DeLong-Bas, N. J. (2001). Women in Muslim family law. Syracuse University Press.

Grigoriadis, I. (2008). Trials of Europeanization: Turkish political culture and the European Union. Springer.

Hacker, D. (2012). Religious tribunals in democratic states: Lessons from the Israeli rabbinical courts. Journal of Law and Religion, 27(1), 59-81. https://doi.org/10.1017/s0748081400000527

Kayan. (2011). Five Years of Legal Aid: Summary and Analysis. Retrieved June, 2015, from http://www.kayan.org.il/Public/ER20110101_5\%20Year\%20Legal\%20Aid\%20Report.pdf

Kitromilides, P. M. (2012). Chandran Kukathas, The Liberal Archipelago. A Theory of Diversity and Freedom. Oxford: Oxford University Press, 2009. xii+ 292pp.£ 48.45 (pbk). Nations and Nationalism, 18(2), 371-373. https://doi.org/10.1111/j.1469-8129.2012.00546_2.x

Klerman, D. (2014). Rethinking personal jurisdiction. Journal of Legal Analysis, 6(2), 245-303. https://doi.org/10.1093/jla/lau007

Lemons, K. (2018). Sharia Courts and Muslim Personal Law in India: Intersecting Legal Regimes. Law \& Society Review, 52(3), 603-629.

Lindsey, T. (2016). 19 Islamic courts or courts for Muslims? Routledge Handbook of Asian Law, 341.

Memisoglu, F. (2007). The European Union's minority rights policy and its impact on the development of minority rights protection in Greece.

Mohammad, M. N., \& Kusrin, Z. M. (2017). Conversion Out of Islam and Its Legal Implications Under the Laws of Malaysia. Ijtimā'iyya: Journal of Muslim Society Research, 2(2), 213-238. https://doi.org/10.24090/ijtimaiyya.v2i2.1638

Ramadan, M. A. (2015). Islamic legal hybridity and patriarchal liberalism in the shari 'a courts in Israel. Journal of Levantine Studies, 4(2), 39.

Rani, B. (2014). Sharia Courts as Informal Justice Institution in India. International Journal of Humanities, Social Sciences and Education, 1(9), 2.

Sandberg, H., \& Sandberg, H. (2017). Dilemmas of Civil Tribunals in Formulating Their Positions toward Religious Tribunals: The Case of Custody of Muslim Children. Journal of Law, Religion and State, 5(3), 214-253.

Sezgin, Y. (2017). Do Not Betray God or Your People: Negotiating Women's Rights Under Muslim Family Laws in Israel and India. J. Int'l \& Comp. L., 4, 81.

Sezgin, Y. (2018). Muslim Family Laws in Israel and Greece: Can Non-Muslim Courts Bring about Legal Change in Shari'a? Islamic Law and Society, 25(3), 235-273. https://doi.org/10.1163/15685195-00253p03 
Shachar, A. (2001). Multicultural jurisdictions: Cultural differences and women's rights. Cambridge University Press.

Shahar, I. (2016). Legal pluralism in the Holy City: competing courts, forum shopping, and institutional dynamics in Jerusalem. Routledge.

Tsavousoglou, İ. (2015). The legal treatment of Muslim minority women under the rule of Islamic law in Greek Thrace. Oslo Law Review, 2(3), 241-262.

Turner, B. S., \& Arslan, B. Z. (2015). Legal pluralism and the Shari'a: a comparison of Greece and Turkey. In the Sociology of Shari'a: Case Studies from around the World (pp. 219-235). Springer, Cham.

\section{Copyrights}

Copyright for this article is retained by the author(s), with first publication rights granted to the journal.

This is an open-access article distributed under the terms and conditions of the Creative Commons Attribution license (http://creativecommons.org/licenses/by/4.0/). 